\title{
Effect of moisture stress on leaf protein, proline, peroxidise activity and yield in released and pre-released genotypes of groundnut (Arachis hypogaea L.)
}

\author{
H. Y. Patil*, Pooja and V. P. Chimmad \\ Department of Crop Physiology, College of Agriculture, University of Agricultural Sciences, Dharwad \\ (Karnataka) India \\ (Email: patil_hy@rediffmail.com;patilhy@uasd.in)
}

\begin{abstract}
The performance of crops need to be assessed for their production under erratic rain fall pattern, increased temperatures, and enhanced atmospheric $\mathrm{CO}_{2}$ concentration. In the present study groundnut was chosen as test crop and selected genotypes [four released (GPBD-4, G2-52, Dh-86 and TMV-2) and four pre-released (Dh-245, Dh-232, Dh-256 and Dh-257)] were studied to quantify the impact of moisture deficit stress at critical growth stages i.e., 40 to $80 \mathrm{DAS}$ and $80 \mathrm{DAS}$ to harvest. Leaf protein and proline increases in tolerant genotypes at higher moisture stress levels than susceptible genotypes as they acts as osmolytes and maintains the turgidity of the cell and hence, checks the water loss and peroxidase enzyme activity which in turn scavenges ROS produced due to stress as a result there was reduction in yield. The genotypes, GPBD-4, Dh-257 and Dh-256 recorded higher per cent increase in leaf soluble protein, leaf proline and peroxidase enzyme activity at all the stages. Increase was higher at 80 DAS to harvest stressed plants than 40 to 80 DAS stressed plants.
\end{abstract}

Key Words : Moisture stress, Leaf soluble protein, Leaf proline, Peroxidase enzyme activity, Yield

View Point Article : Patil, H.Y., Pooja and Chimmad, V.P. (2020). Effect of moisture stress on leaf protein, proline, peroxidise activity and yield in released and pre-released genotypes of groundnut (Arachis hypogaea L.). Internat. J. agric. Sci., 16 (2) : 260-264, DOI:10.15740/ HAS/IJAS/16.2/260-264. Copyright@ 2020: Hind Agri-Horticultural Society.

Article History : Received : 11.04.2020; Revised : 21.05.2020; Accepted : 25.05.2020

\footnotetext{
* Author for correspondence:
} 